\title{
Studies on the Effects of Vermicompost on Growth Parameters and Chlorophyll Content of Bengal Gram (Cicer arietinum L.) var. RSG-896
}

\author{
Preeti Shrimal ${ }^{1}$, T. I. Khan ${ }^{2}$ \\ ${ }^{I}$ (Indira Gandhi Centre for Human Ecology, Environmental and Population Studies, University of Rajasthan, \\ Jaipur-302004, India.) \\ ${ }^{2}$ (Indira Gandhi Centre for Human Ecology, Environmental and Population Studies, University of Rajasthan, \\ Jaipur-302004, India.)
}

\begin{abstract}
The present field experiment was performed in the farmer's field located in Bambala, TehsilSanganer, Jaipur to determine the effects of vermicompost on Bengal gram (Cicer arietinum L.) var. RSG-896. Seeds of Bengal gram (Cicer arietinum L.) var. RSG-896 were exposed to different treatment levels of vermicompost i.e. $T_{1}$ which was control level (soil without vermicompost), $T_{2}, T_{3}, T_{4}, T_{5}$ and $T_{6}$. Plants were harvested at three stages i.e. pre-flowering, peak-flowering and post-flowering stages. With the increase in vermicompost level the root length, shoot length, root dry weight, shoot dry weight and total dry weight were increased to 39.36, 38.55, 36.92, 67.94, 64.26\% respectively. Chlorophyll-a, chlorophyll-b and total chlorophyll contents also increased with increasing level of vermicompost to 86.95, 77.61 and $89.95 \%$ respectively.
\end{abstract}

Keywords: Agricultural fields, Cicer arietinum, growth parameters, vermicomposting.

\section{Introduction}

As India is an agriculture based country, farmers need adequate resources to replenish soil fertility and maintain the productivity of soil. Really, the green revolution has popularized the use of chemical fertilizers to achieve higher productivity. But due to continuous and indiscriminate use of fertilizers, the natural fertility of soil has been lost and this activity has contaminated our soil, water and food. Therefore farmers are in need of searching alternative to replace the chemical fertilizers. [1].

In this context vermicomposting is a system of farming which does not use any form of chemical fertilizers or other agro-chemicals and pesticides. It is dependent entirely on organic sources for crop nutrition and crop husbandry. The main objective of vermicomposting is to develop a sustainable agriculture system, which conserves environment, maintain soil fertility and ensures adequate food production. In this farming system the maintenance of soil fertility and the control of pests and diseases are achieved through the enhancement of biological processes and ecological interaction.

The organic manure (vermicompost) is an eco-friendly, economically viable and ecologically sound practice, that played a significant role in soil biology, chemistry and physics. It is interesting that each year human livestock and crops produce approximately 38 billion metric tons of organic waste worldwide, which may be an efficient source of organic matter supply in soils. According to an estimate around 600 to 700 million tons of agricultural wastes are available in India every year, but most of it remains unutilized. This huge quantity of wastes can be converted into nutrient rich biofertilizers (vermicompost) for sustainable land restoration practices. An estimation showed that $30-35 \%$ of applied N \& P and 70-80\% of K remained in crop residues of food crops. Such nutrient rich crop residue must be prepared before they are used as a fertilizer and earthworms are suitable for this purpose. The earthworms processes organic wastes often referred to as vermicomposts are finely divided peat like materials with high porosity, aeration, drainage and water holding capacity [2]. Vermicomposting has been identified as one of the potential processes in managing waste, since it is a natural process, cost effective and required only shorter duration. The application of vermicompost helps in increasing the organic matter content of the soil, in maintaining soil natural productivity [3]. Organic fertilizers such as compost or manure prepared from vegetative matter or animal excreta have been utilized due to its high value of physical and chemical properties. But in modern agriculture, the chemical fertilizers and pesticides are being applied indiscriminately with desire of getting higher yield which deteriorate the soil fertility as well as crop quality [4]. An organic fertilizer serves as a good and suitable source to supply soil food elements. Among the organic manure, vermicompost is one of the best which contains growth regulators like hormones which increase the growth and yield of crops [5]. Vermicomposting involves the bio-oxidation and stabilization of organic material by the joint action of earth worms and microorganisms. Although it is a microorganism, that biochemically degrade the organic matter, they are the crucial drivers of the process, as they aerate and fragment the substrate there by drastically altering the microbial activity and further decomposition [6]. 
Several workers have reported a positive effect of vermicompost application on growth and productivity of cereals and legumes, ornamental and flowering plants and vegetables. Vermicompost have been reported to improve seed germination, enhanced seedling growth and development and increased overall plant productivity. The organic carbon in vermicompost releases the nutrients slowly and steadily into the system and enables the plant to absorb the nutrients. The soil enriched with vermicompost provides additional substances that are not found in chemical fertilizers [7]. The use of compost and vermicompost has also been observed to improve plant growth and quality. Numerous studies on vermicompost and compost from various sources have been found to promote root formation [8], increase fruit setting and yield [9], [10]. Present paper deals with the study of the effects of various levels of vermicompost on different parameters like root and shoot length, root, shoot and total dry weight and chlorophyll content of Bengal gram (Cicer arietinum L.) var. RSG-896.

\section{Materials and methods}

2.1 Experimental setup: For the experimental study Bengal gram (Cicer arietinum L.) var. RSG-896 was selected as test plant. The Seeds of Bengal gram (Cicer arietinum L.) var. RSG-896 were obtained from Durgapura Research Experiment Station, Jaipur. Vermicompost was collected from M.R. Morarka-GDC Rural research foundation.

Field experiments were carried out in the farmer's field located in Bambala, Tehsil- Sanganer, Jaipur for conducting field experiments for the test plant species Bengal gram (Cicer arietinum L.) var. RSG-896. The total field area divided into six plots. Different level of vermicompost was mixed with soil in the each plot of field area. After mixing of vermicompost with soil ten to fifteen seeds were sown in the beginning in each plot. Three replicates were used for each vermicompost level. After seedling establishment, a uniform population of five plants for each treatment level and each harvest stage was maintained in each plot of field area up to the termination of the experiment. Thus three plots of field area were maintained for each treatment level.

Six treatment levels of different combinations of soil and vermicompost $(\mathrm{VC})$ were maintained viz. $\mathrm{T}_{1}$, $\mathrm{T}_{2}, \mathrm{~T}_{3}, \mathrm{~T}_{4}, \mathrm{~T}_{5}$ and $\mathrm{T}_{6}$ as described below:

$$
\begin{aligned}
& \mathrm{T}_{1}=\quad 0.00 \mathrm{~g} \text { vermicompost }+25,000 \mathrm{gm} \text { soil } \\
& (0.0 \%) \quad(100 \%) \\
& \mathrm{T}_{2}=\quad 312.5 \mathrm{~g} \text { vermicompost }+24,687.5 \mathrm{gm} \text { soil } \\
& \mathrm{T}_{3}=\quad \begin{array}{cc}
(1.25 \%) & (98.75 \%) \\
625 \mathrm{~g} \text { vermicompost } & +24,375 \mathrm{gm} \text { soil }
\end{array} \\
& \text { (2.5\%) (97.50\%) } \\
& \mathrm{T}_{4}=\quad 1250 \mathrm{~g} \text { vermicompost }+23,750 \mathrm{gm} \text { soil } \\
& \mathrm{T}_{5}=\begin{array}{cc}
(5.0 \%) & (95.00 \%) \\
1875 \mathrm{~g} \text { vermicompost } & +23,125 \mathrm{gm} \text { soil }
\end{array} \\
& \text { (7.5\%) } \quad(92.50 \%) \\
& \mathrm{T}_{6}=\quad 2500 \mathrm{~g} \text { vermicompost }+22,500 \mathrm{gm} \text { soil } \\
& (10.0 \%) \quad(90.00 \%)
\end{aligned}
$$

2.2 Growth parameters: The experiment was continued up to the end of post-flowering stage. The plants were harvested at the following three stages.

I. Pre-flowering stage (after 75 days)

II. Peak-flowering stage (after 90 days)

III. Post-flowering stage (after 125 days)

Plants were harvested for growth analysis (like root and shoot length, dry weight of root, shoot and total dry weight). For dry weight determination roots and shoots were separated and dried in hot air oven at $80^{\circ} \mathrm{C}$ for 72 hr.

2.3 Chlorophyll estimation: Samples of known fresh weight of leaves of individual plant species was macerated thoroughly in pestle mortar with a little sand and $80 \%$ acetone. The suspension of macerated material in acetone was centrifuged at $3000 \mathrm{rpm}$ for 2 minutes. Supernatant solution was transferred to a volumetric flask and made up to $25 \mathrm{ml}$. the optical density of the solution was measured by spectrophotometer at $645 \mathrm{~nm}$ and 663 $\mathrm{nm}$.

Following formulae was used to calculate the amount of chlorophyll - $\mathrm{a}$ and chlorophyll- $\mathrm{b}$ [11].

Chl-a mg/gm $=12.7 \times \mathrm{A} 663-2.69 \times \mathrm{A} 645$

Chl-b mg/gm $=22.9 \times$ A645- $4.68 \times$ A663

$\mathrm{Chl}(\mathrm{a}+\mathrm{b}) \mathrm{mg} / \mathrm{gm}=8.02 \times \mathrm{A} 663+20.20 \times \mathrm{A} 645$ 


\section{Results And Discussion}

The average root length, shoot length, root dry weight, shoot dry weight and total dry weight increased with increasing vermicompost levels as given in the Table 1 . Shoot length was $40.44 \mathrm{~cm}$ under controlled condition $\left(\mathrm{T}_{1}\right)$ (soil without vermicompost) at the pre flowering stage, which increased up to $54.80 \mathrm{~cm}$ at the vermicompost level of $\mathrm{T}_{6}$. At the peak flowering stage under controlled condition $\left(\mathrm{T}_{1}\right)$ shoot length was estimated $48.98 \mathrm{~cm}$, which increased up to $67.78 \mathrm{~cm}$ at the vermicompost level of $\mathrm{T}_{6}$. Similarly shoot length was $49.64 \mathrm{~cm}$ at the post flowering stage under controlled condition $\left(T_{1}\right)$ it increased up to $68.78 \mathrm{~cm}$ at the vermicompost level of $\mathrm{T}_{6}$. Root length was $19.70 \mathrm{~cm}$ under controlled condition $\left(\mathrm{T}_{1}\right)$ (soil without vermicompost) at the pre flowering stage increased up to $26.64 \mathrm{~cm}$ at the vermicompost level of $\mathrm{T}_{6}$. At the peak flowering stage under controlled condition $\left(T_{1}\right)$ root length was $22.34 \mathrm{~cm}$, which increased up to $32.62 \mathrm{~cm}$ at the vermicompost level of $\mathrm{T}_{6}$. Similarly root length was estimated $23.88 \mathrm{~cm}$ at the post flowering stage under controlled condition $\left(\mathrm{T}_{1}\right)$ which increased up to $33.28 \mathrm{~cm}$ at the vermicompost level of $\mathrm{T}_{6}$.

Root dry weight was $0.483 \mathrm{gm}$ under controlled condition $\left(\mathrm{T}_{1}\right)$ (soil without vermicompost) at the pre flowering stage which increased up to $0.587 \mathrm{gm}$ at the vermicompost level of $\mathrm{T}_{6}$. At the peak flowering stage under controlled condition $\left(\mathrm{T}_{1}\right)$ root dry weight was $0.562 \mathrm{gm}$, which increased up to $0.717 \mathrm{gm}$ at the vermicompost level of $\mathrm{T}_{6}$. Similarly root dry weight was estimated $0.669 \mathrm{gm}$ at the post flowering stage under controlled condition $\left(\mathrm{T}_{1}\right)$ which increased up to $0.916 \mathrm{gm}$ at the vermicompost level of $\mathrm{T}_{6}$. Shoot dry weight was $2.975 \mathrm{gm}$ under controlled condition $\left(\mathrm{T}_{1}\right)$ (soil without vermicompost) at the pre flowering stage which increased up to $4.381 \mathrm{gm}$ at the vermicompost level of $\mathrm{T}_{6}$. At the peak flowering stage under controlled condition $\left(T_{1}\right)$ shoot dry weight was $3.411 \mathrm{gm}$, which increased up to $5.129 \mathrm{gm}$ at the vermicompost level of $\mathrm{T}_{6}$. Similarly shoot dry weight was estimated $4.948 \mathrm{gm}$ at the post flowering stage under controlled condition $\left(\mathrm{T}_{1}\right)$ which increased up to $8.310 \mathrm{gm}$ at the vermicompost level of $\mathrm{T}_{6}$. Total dry weight was $3.458 \mathrm{gm}$ under controlled condition $\left(\mathrm{T}_{1}\right)$ (soil without vermicompost) at the pre flowering stage which increased up to $4.968 \mathrm{gm}$ at the vermicompost level of $T_{6}$. At the peak flowering stage under controlled condition $\left(T_{1}\right)$ total dry weight was $3.416 \mathrm{gm}$, which increased up to $5.846 \mathrm{gm}$ at the vermicompost level of $\mathrm{T}_{6}$. Similarly total dry weight was estimated $5.617 \mathrm{gm}$ at the post flowering stage under controlled condition $\left(\mathrm{T}_{1}\right)$ which increased up to $9.227 \mathrm{gm}$ at the vermicompost level of $\mathrm{T}_{6}$.

The chlorophyll content also increased with the increasing levels of vermicomposting. Results are given in the Table 1. Chlorophyll-a was $2.093 \mathrm{mg} / \mathrm{gm}$ under controlled condition $\left(\mathrm{T}_{1}\right)$ (soil without vermicompost) at the pre flowering stage, which increased up to $3.132 \mathrm{mg} / \mathrm{gm}$ at the vermicompost level of $\mathrm{T}_{6}$. At the peak flowering stage under controlled condition $\left(\mathrm{T}_{1}\right)$ Chlorophyll-a was $3.188 \mathrm{mg} / \mathrm{gm}$ which increased up to $5.876 \mathrm{mg} / \mathrm{gm}$ at the vermicompost level of $\mathrm{T}_{6}$. Similarly Chlorophyll-a was estimated $2.791 \mathrm{mg} / \mathrm{gm}$ at the post flowering stage under controlled condition $\left(\mathrm{T}_{1}\right)$ which increased up to $5.218 \mathrm{mg} / \mathrm{gm}$ at the vermicompost level of $\mathrm{T}_{6}$. Chlorophyll-b was $1.336 \mathrm{mg} / \mathrm{gm}$ under controlled condition $\left(\mathrm{T}_{1}\right)$ (soil without vermicompost) at the pre flowering stage, which increased up to $2.110 \mathrm{mg} / \mathrm{gm}$ at the vermicompost level of $\mathrm{T}_{6}$. At the peak flowering stage under controlled condition $\left(T_{1}\right)$ Chlorophyll-b was $2.023 \mathrm{mg} / \mathrm{gm}$ which increased up to $3.592 \mathrm{mg} / \mathrm{gm}$ at the vermicompost level of $\mathrm{T}_{6}$. Similarly Chlorophyll-b was estimated $1.823 \mathrm{mg} / \mathrm{gm}$ at the post flowering stage under controlled condition $\left(\mathrm{T}_{1}\right)$ which increased up to $3.238 \mathrm{mg} / \mathrm{gm}$ at the vermicompost level of $\mathrm{T}_{6}$. Total chlorophyll was $3.428 \mathrm{mg} / \mathrm{gm}$ under controlled condition $\left(\mathrm{T}_{1}\right)$ (soil without vermicompost) at the pre flowering stage, which increased up to $5.240 \mathrm{mg} / \mathrm{gm}$ at the vermicompost level of $\mathrm{T}_{6}$. At the peak flowering stage under controlled condition $\left(T_{1}\right)$ total chlorophyll was $5.210 \mathrm{mg} / \mathrm{gm}$ which increased up to $9.466 \mathrm{mg} / \mathrm{gm}$ at the vermicompost level of $\mathrm{T}_{6}$. Similarly total chlorophyll was estimated $4.614 \mathrm{mg} / \mathrm{gm}$ at the post flowering stage under controlled condition $\left(\mathrm{T}_{1}\right)$ which increased up to $8.454 \mathrm{mg} / \mathrm{gm}$ at the vermicompost level of $\mathrm{T}_{6}$.

The analysis of variance (ANOVA) revealed that with the increase in vermicompost levels, there was increase in all the parameters of Bengal gram (Cicer arietinum L.) var. RSG-896. The results are highly significant for harvesting stages, the different vermicompost levels and interactions among the harvesting stages and the vermicompost level maintained in the experiment. The results are non significant for replicates. Mean sum of square (MSS) and $\mathrm{P}$ values are given in the Table 2.

The present study shows that application of vermicompost enhanced the growth percentage in Bengal gram (Cicer arietinum L.) var. RSG-896. This confirms the earlier observations [12], [13], [14] [15] and [16]. Vermicompost enhanced plant production, mineral nutrients and total carotenoids, and this effect was most prominent under organic fertilization [17]. Application of vermicompost was reported by [18], [19], [20], [21] and [22] reported that the vermicompost treated plants exhibit faster and higher growth rate and productivity than the control plants. 
Table: 1 Effects of vermicompost on growth parameters and chlorophyll content of Bengal gram (Cicer arietinum L.) var. RSG-896 through field experiment.

\begin{tabular}{|c|c|c|c|c|c|c|c|c|c|c|c|c|c|c|c|c|c|c|}
\hline Paramters. & & \multicolumn{5}{|c|}{ Pre-flowering stage } & \multicolumn{6}{|c|}{ Peak-flowering stage } & \multicolumn{6}{|c|}{ Post-flowering stage } \\
\hline $\begin{array}{l}\text { Root length } \\
(\mathrm{cm})\end{array}$ & $\begin{array}{c}19.70 \\
\pm 0.148\end{array}$ & $\begin{array}{l}21.22 \\
=0.148 \\
(7.71)\end{array}$ & $\begin{array}{l}23.02 \\
=0.319 \\
(16.85)\end{array}$ & $\begin{array}{l}24.66 \\
=0.151 \\
(25.17)\end{array}$ & $\begin{array}{l}25.68 \\
\pm 0.277 \\
(30.35)\end{array}$ & $\begin{array}{l}26.64 \\
=0.415 \\
(35.22)\end{array}$ & $\begin{array}{l}22.34 \\
\pm 0.240\end{array}$ & $\begin{array}{l}24.60 \\
=0.374 \\
(10.1)\end{array}$ & $\begin{array}{c}26.04 \\
=0.497 \\
(16.56)\end{array}$ & $\begin{array}{c}28.04 \\
\pm 0.665 \\
(25.51)\end{array}$ & $\begin{array}{c}29.52 \\
=0.396 \\
(32.13)\end{array}$ & $\begin{array}{c}32.62 \\
=0.420 \\
(46.01)\end{array}$ & $\begin{array}{l}23.88 \\
=0.370\end{array}$ & $\begin{array}{l}25.58 \\
=0.370 \\
(7.11)\end{array}$ & $\begin{array}{c}27.44 \\
\pm 0.137 \\
(14.90)\end{array}$ & $\begin{array}{l}29.06 \\
=0.207 \\
(21.69)\end{array}$ & $\begin{array}{c}30.62 \\
=0.383 \\
(28.22)\end{array}$ & $\begin{array}{l}33.28 \\
=0.349 \\
(39.36)\end{array}$ \\
\hline $\begin{array}{l}\text { Shootlength } \\
(\mathrm{cm})\end{array}$ & $\begin{array}{l}40.44 \\
=0.421\end{array}$ & $\begin{array}{l}43.84 \\
=0.626 \\
(8.40)\end{array}$ & $\begin{array}{l}47.32 \\
\pm 0.506 \\
(17.01)\end{array}$ & $\begin{array}{c}51.54 \\
\pm 0.350 \\
(27.44)\end{array}$ & $\begin{array}{c}52.86 \\
\pm 0.723 \\
(30.71)\end{array}$ & $\begin{array}{l}54.80 \\
\pm 0.681 \\
(35.50)\end{array}$ & $\begin{array}{l}48.98 \\
=0.476\end{array}$ & $\begin{array}{c}56.96 \\
\pm 0.421 \\
(16.29)\end{array}$ & $\begin{array}{c}60.72 \\
=0.248 \\
(23.96)\end{array}$ & $\begin{array}{c}62.10 \\
=0.212 \\
(26.78)\end{array}$ & $\begin{array}{c}64.38 \\
=0.277 \\
(31.44)\end{array}$ & $\begin{array}{c}67.78 \\
=0.192 \\
(38.38)\end{array}$ & $\begin{array}{l}49.64 \\
\pm 0.114\end{array}$ & $\begin{array}{l}57.42 \\
\pm 0.258 \\
(15.67)\end{array}$ & $\begin{array}{c}61.46 \\
=0.270 \\
(23.81)\end{array}$ & $\begin{array}{l}62.78 \\
\pm 0.109 \\
(26.47)\end{array}$ & \begin{tabular}{c|}
65.98 \\
\pm 0.238 \\
$(32.91)$
\end{tabular} & $\begin{array}{l}68.78 \\
=0.192 \\
(38.55)\end{array}$ \\
\hline $\begin{array}{c}\text { Shoot dry } \\
\text { weight (gm) }\end{array}$ & $\begin{array}{l}2.975 \\
=0.005\end{array}$ & $\begin{array}{c}3.282 \\
\pm 0.004 \\
(10.31)\end{array}$ & $\begin{array}{l}3.611 \\
=0.02 \\
(21.7)\end{array}$ & $\begin{array}{l}3.897 \\
=0.018 \\
(30.99)\end{array}$ & $\begin{array}{l}4.151 \\
\pm 0.010 \\
(39.52)\end{array}$ & $\begin{array}{l}4.381 \\
=0.011 \\
(47.26)\end{array}$ & $\begin{array}{l}3.411 \\
\pm 0.014\end{array}$ & $\begin{array}{l}3.868 \\
\pm 0.012 \\
(13.39)\end{array}$ & $\begin{aligned} & 4.235 \\
&= 0.003 \\
&(24.15)\end{aligned}$ & $\begin{array}{c}4.556 \\
\pm 0.004 \\
(33.56)\end{array}$ & $\begin{array}{l}4.925 \\
\pm 0.003 \\
(44.38)\end{array}$ & $\begin{array}{c}5.129 \\
\pm 0.006 \\
(50.36)\end{array}$ & $\begin{array}{l}4.948 \\
=0.006\end{array}$ & $\begin{array}{l}5.699 \\
\pm 0.005 \\
(15.17)\end{array}$ & $\begin{array}{c}6.278 \\
=0.004 \\
(26.87)\end{array}$ & $\begin{array}{l}6.880 \\
=0.006 \\
(39.04)\end{array}$ & $\begin{array}{c}7.480 \\
\pm 0.004 \\
(51.17)\end{array}$ & $\begin{array}{l}8.310 \\
\pm 0.007 \\
(67.94)\end{array}$ \\
\hline $\begin{array}{c}\text { Total dry } \\
\text { weight }(\mathrm{gm})\end{array}$ & $\begin{array}{l}3.458 \\
\pm 0.021\end{array}$ & $\begin{array}{l}3.784 \\
=0.005 \\
(9.42)\end{array}$ & $\begin{array}{l}4.142 \\
=0.008 \\
(19.78)\end{array}$ & $\begin{array}{l}4.455 \\
\pm 0.050 \\
(28.83)\end{array}$ & $\begin{array}{l}4.721 \\
\pm 0.015 \\
(36.52)\end{array}$ & $\begin{array}{l}4.968 \\
\pm 0.031 \\
(43.66)\end{array}$ & $\begin{array}{c}3.416 \\
\pm 0.032\end{array}$ & $\begin{array}{l}4.464 \\
\pm 0.031 \\
(30.67)\end{array}$ & $\begin{array}{c}4.864 \\
=0.005 \\
(42.38)\end{array}$ & $\begin{array}{c}5.211 \\
\pm 0.004 \\
(52.54)\end{array}$ & $\begin{array}{l}5.610 \\
\pm 0.003 \\
(64.22)\end{array}$ & $\begin{array}{c}5.846 \\
\pm 0.009 \\
(71.13)\end{array}$ & $\begin{array}{l}5.617 \\
\pm 0.013\end{array}$ & $\begin{array}{l}6.420 \\
=0.005 \\
(14.29)\end{array}$ & $\begin{array}{c}7.048 \\
=0.008 \\
(25.47)\end{array}$ & $\begin{array}{l}7.688 \\
\pm 0.010 \\
(36.87)\end{array}$ & $\begin{array}{l}8.348 \\
\pm 0.009 \\
(48.62)\end{array}$ & $\begin{array}{l}9.227 \\
=0.010 \\
(64.26)\end{array}$ \\
\hline $\begin{array}{l}\text { Chlorophyll-b } \\
\text { (mg gm) }\end{array}$ & $\begin{array}{l}1.336 \\
\pm 0.239\end{array}$ & $\begin{array}{l}1.453 \\
\pm 0.143 \\
(8.75)\end{array}$ & $\begin{array}{l}1.508 \\
\pm 0.115 \\
(12.87)\end{array}$ & $\begin{array}{l}1.679 \\
\pm 0.135 \\
(25.67)\end{array}$ & $\begin{array}{l}1.854 \\
\pm 0.141 \\
(38.77)\end{array}$ & $\begin{array}{l}2.110 \\
=0.138 \\
(57.93)\end{array}$ & $\begin{array}{l}2.023 \\
\pm 0.332\end{array}$ & $\begin{array}{l}2.382 \\
=0.312 \\
(17.74)\end{array}$ & $\begin{array}{c}2.700 \\
=0.136 \\
(33.46)\end{array}$ & $\begin{array}{c}2.976 \\
\pm 0.107 \\
(47.10)\end{array}$ & $\begin{array}{l}3.226 \\
=0.168 \\
(59.46)\end{array}$ & $\begin{array}{c}3.592 \\
=0.284 \\
(77.55)\end{array}$ & $\begin{array}{l}1.823 \\
\pm 0.253\end{array}$ & $\begin{array}{l}2.024 \\
=0.256 \\
(11.02)\end{array}$ & $\begin{array}{c}2.323 \\
=0.127 \\
(27.42)\end{array}$ & $\begin{array}{l}2.716 \\
=0.113 \\
(48.98)\end{array}$ & $\begin{array}{l}3.071 \\
\pm 0.175 \\
(68.45)\end{array}$ & $\begin{array}{l}3.238 \\
=0.078 \\
(77.61)\end{array}$ \\
\hline $\begin{array}{c}\text { Total } \\
\text { chlorophyll } \\
\text { (mggm) }\end{array}$ & $\begin{array}{c}3.428 \\
=0.349\end{array}$ & $\begin{array}{l}3.643 \\
=0.196 \\
(6.27)\end{array}$ & $\begin{array}{l}3.881 \\
=0.129 \\
(13.21)\end{array}$ & $\begin{array}{l}4.255 \\
=0.095 \\
(24.12)\end{array}$ & $\begin{array}{l}4.668 \\
\pm 0.092 \\
(36.17)\end{array}$ & $\begin{array}{l}5.240 \\
=0.086 \\
(52.85)\end{array}$ & $\begin{array}{c}5.210 \\
=0.588\end{array}$ & $\begin{array}{l}6.105 \\
=0.436 \\
(17.17)\end{array}$ & $\begin{array}{c}6.857 \\
=0.269 \\
(31.61)\end{array}$ & $\begin{array}{l}7.525 \\
\pm 0.306 \\
(44.43)\end{array}$ & $\begin{array}{l}8.332 \\
=0.410 \\
(59.92)\end{array}$ & $\begin{array}{c}9.466 \\
=0.641 \\
(81.68)\end{array}$ & $\begin{array}{l}4.614 \\
=0.155\end{array}$ & $\begin{array}{l}5.126 \\
=0.172 \\
(11.99)\end{array}$ & $\begin{array}{l}6.016 \\
=0.090 \\
(32.84)\end{array}$ & $\begin{array}{l}6.723 \\
=0.104 \\
(49.40)\end{array}$ & $\begin{array}{l}7.563 \\
=0.091 \\
(69.07)\end{array}$ & $\begin{array}{l}8.454 \\
=0.083 \\
(89.95)\end{array}$ \\
\hline
\end{tabular}

*Mean of five replicates \pm standard deviation; Data in parenthesis denotes percentage increase

Table 2: Mean sum of squares due to effects of vermicompost on different parameters of Bengal gram (Cicer arietinum L.) var. RSG-896 through field experiment.

\begin{tabular}{|c|c|c|c|c|c|c|c|c|c|}
\hline Source & DF & Root length & Bboot lenghti & $\begin{array}{l}\text { Root dry } \\
\text { weight }\end{array}$ & $\begin{array}{l}\text { Shoot dry } \\
\text { weight }\end{array}$ & $\begin{array}{l}\text { Total dry } \\
\text { weight }\end{array}$ & Chlorophiyl-a & Chlorophyllsb & $\begin{array}{c}\text { Total } \\
\text { chlorophyll }\end{array}$ \\
\hline Replicatei & 4 & $\begin{array}{c}0.164 \\
(0.279: 91)\end{array}$ & $\begin{array}{c}0.303 \\
(0.007849)\end{array}$ & $\begin{array}{c}0,000 \\
(0.527468)\end{array}$ & $\begin{array}{c}0.00019 \\
(0.34947)\end{array}$ & $\begin{array}{c}0.001 \\
(0.262215)\end{array}$ & $\begin{array}{c}0.062 \\
(0.104407)\end{array}$ & $\begin{array}{c}0.011 \\
(0.905443)\end{array}$ & $\begin{array}{c}0,008 \\
(0.392694)\end{array}$ \\
\hline Stage & 2 & $\begin{array}{c}191294 \\
(4.316 \cdot 57 * *)\end{array}$ & $\begin{array}{c}1473236 \\
(1.31 E-84 * *)\end{array}$ & $\begin{array}{c}0.489 \\
(4,13 E-72 * *)\end{array}$ & $\begin{array}{c}68.800 \\
(3.4 \mathrm{E} \cdot 139 * *)\end{array}$ & $\begin{array}{c}82.277 \\
(2.85 .130 * *)\end{array}$ & $\begin{array}{c}29.349 \\
\left(2.86 \mathrm{E} \cdot 50^{* *}\right)\end{array}$ & $\begin{array}{c}\text { Tr.084 } \\
(6.736 \cdot 33 * \cdots)\end{array}$ & $\begin{array}{c}75.243 \\
(4.085-49 * *)\end{array}$ \\
\hline Treatment & 5 & $\begin{array}{c}157519 \\
(2.13 E-65 *)\end{array}$ & $\begin{array}{c}389.238 \\
(2.05 \mathrm{E}-\mathrm{-82**})\end{array}$ & $\begin{array}{c}0.060 \\
\left(1.14 \mathrm{E}-52^{*}\right)\end{array}$ & $\begin{array}{c}9.559 \\
(2.2 \mathrm{E}-121 *)\end{array}$ & $\begin{array}{c}12.592 \\
(7.8 \mathrm{BE}-114 * *)\end{array}$ & $\begin{array}{c}1.588 \\
(1.12 \mathrm{E}-43 *)\end{array}$ & $\begin{array}{c}3.265 \\
(0.22-27 \ldots)\end{array}$ & $\begin{array}{c}22.395 \\
(6.01 \mathrm{E}-43 *)\end{array}$ \\
\hline $\begin{array}{l}\text { Tuteriction } \\
\text { (stagexTreatmeno }\end{array}$ & 10 & $\begin{array}{c}1.905 \\
(4.991-14 * *)\end{array}$ & $\begin{array}{c}6.262 \\
(2.791-25 * *)\end{array}$ & $\begin{array}{c}0.004 \\
(1.65 \mathrm{E}-21 * 4)\end{array}$ & $\begin{array}{c}0.804 \\
(9 E-90 * *)\end{array}$ & $\begin{array}{c}0.782 \\
(1.8 E-80 * *)\end{array}$ & $\begin{array}{c}0.475 \\
(8.14 E-14 * 0)\end{array}$ & $\begin{array}{c}\text { 0.146 } \\
(0.000906 *)\end{array}$ & $\begin{array}{c}\text { मान } \\
(1.17 \mathrm{E}-12 * *)\end{array}$ \\
\hline
\end{tabular}

Data in parenthesis indicate $\mathrm{P}$ values.

** p $<.01$ e.i. Highly Significant

$*$ p $<.05$ e.i. Significant at $5 \%$ only

\section{Conclusion}

The application of vermicomposts in the field enhances the quality of soils by increasing microbial activity and microbial biomass which are key components in nutrient cycling, production of plant growth regulators and protecting plants soil-borne disease and arthropod pest attacks. From the field experiment, it was found that increasing dose of vermicompost at highest level $\mathrm{T}_{6}$ resulted higher growth, yield and quality of Bengal gram (Cicer arietinum L.) var. RSG-896 crop as compared to rest treatment levels. Compared to controlled condition $\left(\mathrm{T}_{1}\right)$ (soil without vermicompost) the growth of plant was better in the levels in which vermicompost was added. With the increase in amount of vermicompost the growth was found to be encouraging upto $\mathrm{T}_{6}$. The results revealed that there is a need to shift from use of chemical fertilizers to organic farming by using vermicompost. These results can be applied at larger farm levels for safe and sustainable agriculture. 


\section{Acknowledgements}

The authors are thankful to the Director, Indira Gandhi Centre for Human Ecology, Environmental and Population Studies, University of Rajasthan, Jaipur for providing necessary facilities.

\section{References}

[1] S.U. Sundari, and A. Gandhi, Effect of vermicompost prepared from different Organic wastes on growth and yield of Okra (Abelmoschus esculentus L.(Moench)), International Journal of Recent Scientific Research, 4(5), 2013, 568-571.

[2] C. A. Edwards, \& I. Burrows, The Potential of Earthworms Composts as Plant Growth Media. In C. A. Edward, and E. F. Neuhauser (Eds.), Earthworms in Waste and Environmental Management (ISBN 90-5103-017-7, pp. 21-32). SPB Academic Publishing, The Hague, Netherlands, 1988.

[3] A. K. Gupta, B. Ray, M. P. Singh, V. Upadhyaya and C. K. Singh, Effect of fertilizers and vermicompost on growth, yield and biochemical changes in Abelmoschus esculentus. Plant Archieves, Vol.11 (1), 2011, pp.285-287.

[4] D.A. Ntanos, and S.D. Koutroubas, Dry matter and N accumulation and translocation for indica and Japonica rice under Mediterranean conditions, Field Crops Sci., 74(1), 2002, 93-101.

[5] L.P. Canellas, F.L. Oliveres, A.L. Olorovola, and A.R. Facanda, Humic acid isolated from Earthworm compost enhance root elongation; aerial root emergence and plasma membrane H+ ATP activity Maize root. Plant Physiol., 130(4), 2002, $1951-1957$.

[6] J. Dominguez, C.A. Edwards, and S. Subler, A comparison of composting and vermicomposting, Biocyvle, 4, 1997, 57-59.

[7] A. A. Ansari, and K. Sukhraj, Effect of vermiwash and vermicompost on soil parameters and productivity of Okra (Abelmoschus esculentus) in Guyana, Middle - East Journal of Scientific Research 6(5), 2010, 429-435.

[8] N. Q. Arancon, P. A. Galvis, \& C. A. Edwards, Suppression of Insect Pests Populations and Damage to Plants by Vermicompost, J. Of Bioresource Technology, 96, 2005, 1137 - 1142.

[9] R. M. Atiyeh, S. Lee, C. A. Edwards, N. Q. Arancon, \& J. D. Metzger, The Influence of Humic Acids Derived from EarthwormProcessed Organic Wastes on Plant Growth. J. of Bioresource Technology, 84(1), 2002, 7-14.

[10] N. Q. Arancon, C. A. Edwards, P. Bierman, C. Welch, \& J. D. Metzger, Influences of Vermicomposts on Field Strawberries: 1. Effects on Growth and Yields, Bioresource Technology, 93(2), 2004, 145 -153.

[11] D.I. Arnon, Copper enzymes in isolated chloroplasts polyphenolxidase in Beta vulgaris, Plant Pysiolo., 1949, $24,1-15$.

[12] N. Q. Arancon, , P. Bierman, J. D. Metzger, S. Lee, \& C. Welch, Effects of Vermicomposts on Growth and Marketable Fruits of Field-grown Tomatoes, Peppers and Strawberries. Pedobiologia, 47, 2003, 731-735.

[13] C. A. Edwards, \& N. Q. Arancon, Vermicompost Supress Plant Pests and Diseases Attacks. Retrieved from http://www.rednova.com/display/?id =55938 In REDNOVA NEWS, 2004.

[14] M.N. Alam, M.S. Jahan, M.K. Ali, M.A. Ashraf, and M.K. Islam, Effect of vermicompost and chemical fertilizers on growth, yield and yield components of Potato in Barind soils of Bangladesh. Journal of Applied Sciences Researc., 3(12), 2007, 1879-1888.

[15] A.A. Ansari, Effect of vermicompost and vermiwash on the productivity of Spinach (Spinacia oleracea), Onion (Allium cepa) and Potato (Solanum tuberosum). World Journal of Agricultural Sciences, 4 (5), 2008, 554-557.

[16] A.A. Ansari, Effect of vermicompost on the productivity of Potato (Solanum tuberosum), Spinach (Spinacia oleracea) and Turnip (Brassica campestris). World Journal of Agricultural Sciences. 4 (3), 2008, 333-336.

[17] Pant, A.P., T. J.K. Radovich, N.V. Hue, S.T. Talcottb, and K. A. Krenekb, Vermicompost extracts influence growth, mineral nutrients, phytonutrients and antioxidant activity in Pak choi (Brassica rapa cv. Bonsai, Chinensis group) grown under vermicompost and chemical fertilizer. J Sci Food Agric, 2009.

[18] E. Chamani, D.C. Joyce, and A. Reihanytabar, Vermicompost effects on the growth and flowering of Petunia hybrida 'Dream Neon Rose'. American-Eurasian J. Agric. and Environ. Sci. 3 (3), 2008, 506-512.

[19] S. Suthar, Impact of vermicompost and composted farmyard manure on growth and yield of garlic (Allium stivum L.) field crop. International Journal of Plant Production. 3 (1), 2009, 27-38.

[20] J. Sinha, C.K. Biswas, A. Ghosh, and A. Saha, Efficacy of vermicompost against fertilizers on Cicer and Pisum and on population diversity of $\mathrm{N}_{2}$ fixing bacteria. Journal of Environmental Biology, 31(3), 2010, 287-292.

[21] K.Tharmaraj, P. Ganesh, K. Kolanjinathan, R. S. Kumar, and A. Anandan, Influence of vermicompost and vermiwash on physico chemical properties of rice cultivated soil. Curr. Bot. 2(3), 2011, 18-21.

[22] G.K. Chanda, G. Bhunia, and S. K. Chakraborty, The effect of vermicompost and other fertilizers on cultivation of tomato plants Journal of Horticulture and Forestry, 3(2), 2011, 42-45. 